\title{
Perceptions of Social Context and Intention to Quit: The Mediating Role of Work Engagement and Interpersonal Strain
}

\author{
Silvia De Simone ${ }^{1, *(\mathbb{D}}$, Gianfranco Cicotto $^{2}\left(\mathbb{D}\right.$, Roberto Cenciotti $^{3}$ and Laura Borgogni ${ }^{3}$ \\ 1 Department of Pedagogy, Psychology and Philosophy, University of Cagliari, Via Is Mirrionis, 1, \\ 09123 Cagliari, Italy \\ 2 Department of Economics, Universitas Mercatorum Roma, Piazza Mattei, 00186 Roma, Italy; \\ dott.cicotto@gmail.com or gianfranco.cicotto@unimercatorum.it \\ 3 Department of Psychology, Sapienza University of Rome, Via dei Marsi, 00185 Roma, Italy; \\ rc10phd@gmail.com (R.C.); laura.borgogni@uniroma1.it (L.B.) \\ * Correspondence: desimone@unica.it or desimone.silvia@gmail.com; Tel.: +39-0706757513; Fax: +39-070274778
}

Citation: De Simone, S.; Cicotto, G.; Cenciotti, R.; Borgogni, L. Perceptions of Social Context and Intention to Quit: The Mediating Role of Work Engagement and Interpersonal Strain. Sustainability 2021, 13, 7554. https:// doi.org/10.3390/su13147554

Academic Editors: Amelia Manuti, Antonino Callea and Maria Luisa Giancaspro

Received: 8 June 2021

Accepted: 1 July 2021

Published: 6 July 2021

Publisher's Note: MDPI stays neutral with regard to jurisdictional claims in published maps and institutional affiliations.

Copyright: (c) 2021 by the authors. Licensee MDPI, Basel, Switzerland. This article is an open access article distributed under the terms and conditions of the Creative Commons Attribution (CC BY) license (https:// creativecommons.org/licenses/by/ $4.0 /)$.

\begin{abstract}
Several studies have investigated turnover intention and its predictors underlining the role of organisational conditions and personal resources. This study focused on the role of the Perceptions of Social Context (PoSC) and Work Engagement as personal resources that can create healthy and productive organisations. The aim of this study is to investigate the factors that contribute to intention to quit focusing on the PoSC, including Work Engagement and a construct that describes mental and emotional detachment from other individuals in work contexts (Interpersonal Strain). A total of 647 employees of an Italian organisation completed a self-report questionnaire. A structural equations model was tested, the findings of which show that work engagement negatively predicts intention to quit, whereas interpersonal strain positively predicts this outcome. Moreover, the PoSC of the immediate supervisor and the PoSC of colleagues have negative mediated effects on intention to quit by reinforcing work engagement and by reducing interpersonal strain, respectively. Finally, the PoSC of management also have negative effects on intention to quit, both directly and by increasing work engagement. Nevertheless, it is now possible to plan different actions and interventions, taking into account these findings to enhance workplace well-being.
\end{abstract}

Keywords: Perceptions of Social Context (PoSC); intention to quit; work engagement; interpersonal strain

\section{Introduction}

Today's job market is characterised by insecurity, instability, and turbulence [1], and the well-being of workers and organisations is highly at risk [2,3]. The psychology of sustainability and sustainable development is a new primary prevention approach that promotes well-being in the workplace $[4,5]$. This perspective sees healthy workers as flourishing and resilient and underlines the importance of making positive work environments, by creating positive relationships, to promote individual and organisational well-being $[3,6,7]$. According to the paradigm of sustainability, it is important to consider the role of both the positive organisational conditions and the personal resources of workers that can make workplaces healthy and productive $[1,8]$. Based on these premises, it is important that studies focus on the conditions that can improve workers' well-being, contributing to making conditions that can promote organisational sustainability $[8,9]$.

Some studies related to well-being in the workplace indicate that work engagement is associated with lower turnover [10-13] and that work stressors are considered as indicators of turnover intention [14,15].

Voluntary turnover is a worrying global phenomenon that has negative consequences for an organisation and affects the quality of its service and workplace well-being [16,17]. High employee turnover decreases customer satisfaction and loyalty and thus impoverishes 
the brand's image [18]. A high turnover is so expensive for companies that, in the long run, they could lose their competitiveness as a result. Therefore, it is crucial for organisations to better understand the factors contributing to employee turnover [19-22].

Intention to quit, also called turnover intention, has been identified as the most predictive variable of employee turnover $[14,23,24]$. Studies on the antecedents of employee turnover intention have represented a key area of research in the organisational behaviour literature [25-28]. These studies have shown how turnover intention is related to job satisfaction, organisational commitment, workgroup cohesion, job stress, job involvement $[25,29,30]$, and perceived supervisor and organisational support [27,28].

Several studies have investigated work engagement as an antecedent of turnover intention, although few studies have considered the role of relational stressors on the intention to leave a company. Specifically, interpersonal strain, in contrast to work engagement, represents discomfort and disengagement in relationships at work in response to relational pressures [31,32]; however, few studies have been conducted in relation to counterproductive behaviours. The interpersonal strain at work construct was introduced in order to re-evoke the interpersonal nature that characterised burnout in its original definition. Interpersonal strain, as opposed to the depersonalisation of the original burnout syndrome that referred only to the receiver/caregiver relationship, explains the social strain reaction associated with all relationships at work such as with colleagues, supervisors, and clients. While previous studies have shown that good levels of engagement reduce turnover intention [11,12,33-36], we are not aware of any studies that have examined the effects of interpersonal strain on turnover intention.

The present study aims to investigate the factors that contribute to intention to quit, including positive involvement at work and detachment due to pressing relationships, and focusing on the Perceptions of Social Context (PoSC), a key resource able to promote positive organisational behaviours and to prevent counterproductive behaviours [37-39].

PoSC [38-41] is a construct that refers to an individual's perceptions of their expected behaviours by organisational social components such as top management, immediate supervisors, and colleagues. PoSC has previously been studied in relation to collective efficacy [38,41], job burnout [39,42], self-efficacy [38,40,41,43,44], job satisfaction, and organisational commitment [45]. On the other hand, only one study has investigated the relationship between employees' PoSC and work engagement [46]. Similarly, only one study has explored the association between the PoSC and interpersonal strain [42].

The contribution of the present study to the literature is twofold; this is the first empirical research investigating the contribution to turnover intention of the PoSC of top management, immediate supervisors, and colleagues. Secondly, this paper is the first to examine the extent to which work engagement and interpersonal strain mediate the relationship between PoSC and intention to quit. We expect to confirm the positive relationships between PoSC and work engagement and between interpersonal strain and intention to quit, and the negative relationships between PoSC and interpersonal strain and between work engagement and intention to quit. In addition, we propose to explore the mediating role of work engagement and interpersonal strain between PoSC and the intention to leave the organisation.

The findings of this study have implications for theory and practice and offer new insights in order to improve the organisational strategies useful in reducing intention to quit and voluntary turnover behaviours.

\subsection{From PoSC to Work Engagement}

The study of the organisational context with regard to individual behaviour is increasingly gaining relevance [47]. This is particularly true in the contemporary period characterised by renewed attention on the specificity and customisation of processes and practices within organisations. The impact of context has been underappreciated in organisational studies, especially the potential of context to explain unusual behaviours and counterintuitive findings [48]. The characteristics of the context can shape personality and 
affect work designs [49]. Context is a set of situational opportunities and constraints that affect organisational behaviours and their meaning [50]. Borgogni and colleagues [38,40,41] introduced the concept of PoSC, defined as shared perceptions of prototypic social context components $[38,40,41]$. The focus is explicitly on the social features within organisational settings, the main social constituencies (i.e., top management, immediate supervisor, and colleagues); these are considered mostly because they are structurally defined, and they are able to satisfy important social needs experienced by employees in the workplace (ibidem). The perceptions of the immediate supervisor refer to supervisors treating employees with equity, fostering employee participation, supporting their professional development, clearly communicating the goals to employees, providing them with the necessary information, and supporting subordinates' needs. The perceptions of colleagues refer to crucial aspects characterising peer relationships at work, namely reciprocal support, atmosphere, collaboration, and competencies' integration. The perceptions of top management are related to the management's behaviours in clearly defining tasks, goals, and activities, in encouraging an individual's professional development, in supporting employees' needs, in treating employees fairly and transparently, and in offering training opportunities for employees.

Studies on PoSC have focused on how colleagues' perceptions related to their supportiveness, trust, and cohesiveness, while direct supervisors' perceptions referred to giving support and feedback to facilitate professional development, and the perceptions of top management related to clear communication and creating opportunities for development affecting organisational behaviours [37-40,45].

A recent study by Consiglio and colleagues [51] identified that positive changes in an employee's PoSC (colleagues, immediate supervisor, and top management) mediate the relationship between self-efficacy and work engagement. Work engagement refers to a positive and fulfilling state of mind typifying employees strongly involved and happily absorbed in their work [52]. Engaged employees are energetic and enthusiastically involved in their job [53]. Work engagement refers to high levels of energy and a willingness to be persistently enthusiastic about one's work [54]. This state of being fully concentrated on work makes time pass quickly and diminishes distractions. Several research studies have found that job resources predict work engagement. Job resources comprise task characteristics and aspects related to relationships such as social support from colleagues and feedback from supervisors [12,55]. Social support from colleagues and supervisors is positively associated with work engagement [53,56-58]. Additionally, it has been found that social support is an important antecedent of employees' work engagement $[12,55,59]$.

Previous research suggests that factors related to organisational variables, including those with immediate supervisors, top managers, and coworkers, are predictors of employee work engagement $[12,55,60,61]$. When workers perceive their supervisors or top management as supportive, they will feel encouraged to reciprocate by engaging more in their work $[12,60]$. Social resources such as social support from immediate supervisors and colleagues are positively associated with work engagement [62], and perceived organisational support has been linked to work engagement [63].

Starting from the results of Consiglio and colleagues [51], which stressed that an increase in PoSC contributes to work engagement, and referring to the presented literature, we formulated the following hypothesis:

Hypothesis 1 (H1). The PoSC of top management, immediate supervisors, and colleagues are positively related to work engagement.

Our study considered the perceived organisational behaviours enacted by supervisors, colleagues, and top management to be job resources that refer to social aspects that can promote the positive and fulfilled state of mind that characterises work engagement.

\subsection{From PoSC to Interpersonal Strain}

Interpersonal strain is a construct that has been recently developed as a new dimension related to burnout and that measures the consequences of pressures from social relation- 
ships at work [31,32]. Starting from the concept of social withdrawal in personal relationships, interpersonal strain is defined as a defensive and avoidant reaction towards demanding relationships at work [64]. This construct represents a specific psychological discomfort and disengagement from relationships at work in response to overwhelming social and emotional demands and is applicable to all organisational contexts in which the interpersonal relationship is central to work activities. Interpersonal strain intercepts defensive reactions in the face of strong relational pressures [31,32]. It is a feeling of uneasiness and detachment that workers feel when they face the different relational requests coming from colleagues, supervisors, etc., and manifests itself with an attitude of distance from others.

There are still few studies that have rejected this construct in organisational contexts $[32,42,46,65,66]$. Previous studies have demonstrated that interpersonal strain is associated with exhaustion and cynicism, the two core burnout components [32], and with work self-efficacy, job demands, job resources, and sickness absenteeism [46,67]. In another study, a strong relationship between interpersonal strain and both emotional dissonance and health symptoms has been found [65].

Very little is known about the relationship of interpersonal strain with PoSC. One recent study [42] investigated the association between PoSC and interpersonal strain, along with the other dimensions of job burnout (exhaustion and cynicism) in health services organisations. The results confirm the association between PoSC and job burnout and show the role of teamwork perceptions and perceptions of time pressure in predicting interpersonal strain. Consistent with these results, we assume that people that have positive perceptions about their relationship experiences at work avoid disinvesting from these relationships.

As such, we formulated the following hypothesis:

Hypothesis $\mathbf{2}$ (H2). The PoSC of top management, immediate supervisors, and colleagues are negatively related to interpersonal strain.

This study considered positive perceptions related to behaviours central to the development and involvement of workers by the top management and supervisors, as well as colleagues' positive perceptions in terms of support and collaboration as job resources that can prevent psychological discomfort and disengagement from relationships at work.

\subsection{From Work Engagement and Interpersonal Strain to Intention to Quit}

Work engagement, a positive and fulfilling state of mind typifying employees strongly involved in their work [52], is usually positively associated with work performance and negatively with withdrawal behaviours such as absenteeism and turnover [68]. The literature examining the relationship between employees' turnover intention and work engagement suggests a protective influence with respect to withdrawal behaviours [10-13]. Several researchers have studied the influence of work engagement in intention to quit [69-75].

Interpersonal strain, which is psychological distress resulting from interpersonal interactions [76] that is manifest with indifferent, harsh, and reserved behaviour towards other people [32], is potentially able to generate a disengagement reaction at work [77]. In fact, interpersonal strain has been associated with absences [65], emotional dissonance, and health symptoms [66]. A recent study [15] revealed that interpersonal strain at work fully mediates the link between relationship conflict and turnover intention.

In accordance with these findings, we postulate that the experiences of being engaged at work act on the desire to stay at work and, that, in contrast, discomforting and disengaging relationships at work in response to relational pressures feed the desire to look for another job. Based on this, we assume that:

Hypothesis $3 \mathbf{( H 3 )}$. Work engagement is negatively related to intention to quit and interpersonal strain is positively related to intention to quit.

This study considered that work engagement is able to prevent turnover intention and interpersonal strain able to reinforce the intention to leave the organisation. 


\subsection{From PoSC to Intention to Quit: The Mediating Role of Work Engagement and Interpersonal Strain}

Several scholars have investigated the mediating role of job burnout $[78,79]$ in the relationship between conflicting relationships and both performance and intention to quit [15] and in those between social work support and customer service failure [80]. Furthermore, the mediating role of work engagement in the relationship between organisational support and quality of service [79], as well as its role in mediating the relationship between social support at work and performance [81], and those between organisational support and intention to quit work [11] has been investigated.

Consistent with these results, we postulate that the negative relationship between PoSC and intention to quit may be mediated by the positive state of being strongly involved and absorbed in one's work and by psychological discomfort and disengagement from relationships at work. Underpinning this assumption is that the positive perceptions of relationships with colleagues, supervisors, and management should affect the intention to leave the organisation because they stimulate positive experiences of being engaged at work and prevent stress resulting from interpersonal interactions at work. Through work engagement, on the one hand, and interpersonal strain on the other, the PoSC may decrease one's intention to quit. That is, the positive PoSC, which can be considered to be job resources, generate the engagement that leads people to be involved in work and therefore less interested in looking for another job. On the other hand, negative perceptions of the main social constituencies within organisational settings lead to the desire to change work through uneasiness and detachment from others. Hence, we will test the following hypothesis:

Hypothesis 4 (H4). Work engagement and interpersonal strain mediate the relationships between PoSC and intention to quit.

The research hypotheses presented in the previous sections are reported in the following theoretical model (Figure 1).

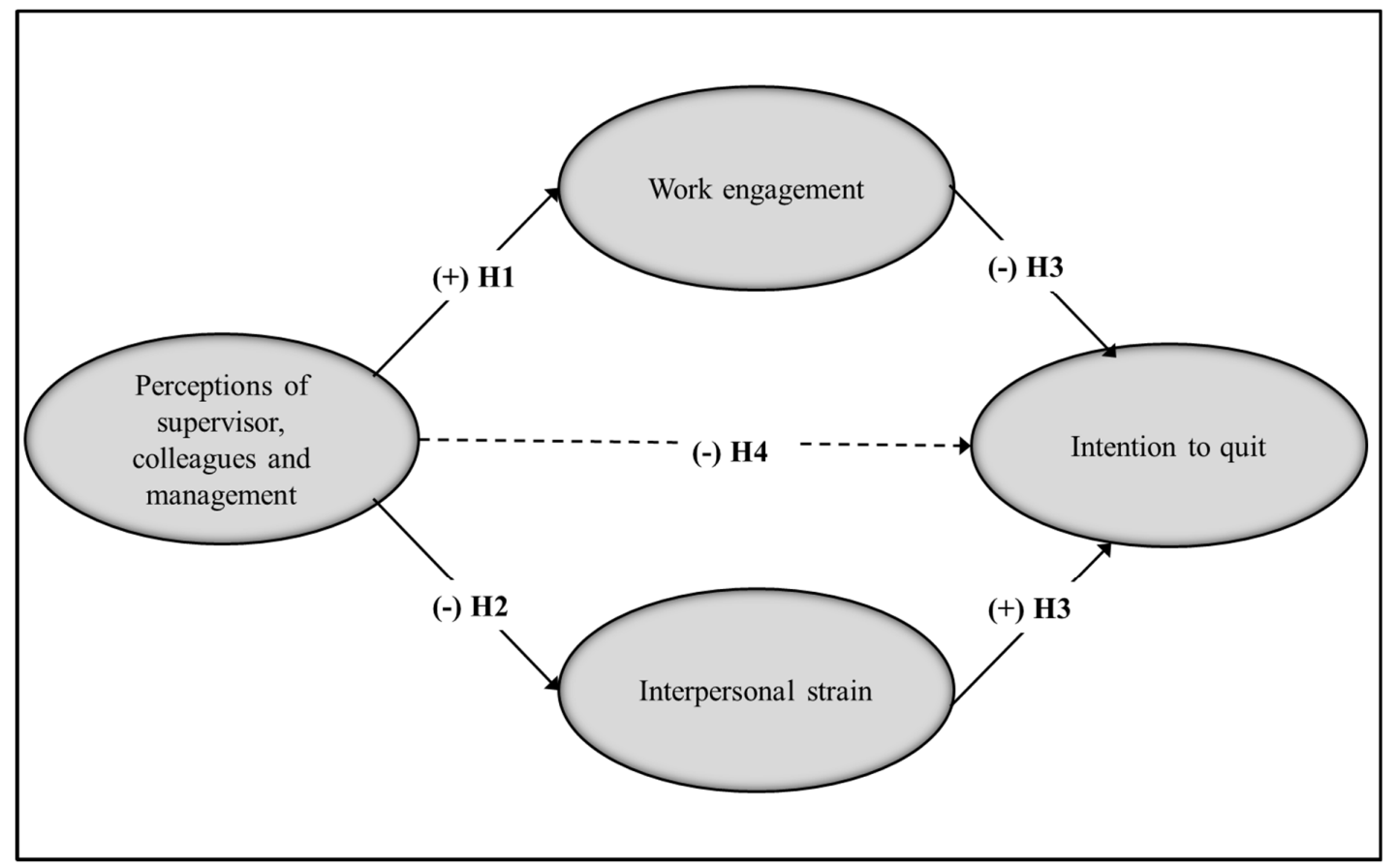

Figure 1. Theoretical model. Notes. Hypotheses concerning direct relationships are on solid lines. Hypothesis regarding mediated relationships is on a dashed line. 
The model shows that the PoSC of top management, immediate supervisors, and colleagues are positively related to work engagement, negatively to interpersonal strain and intention to quit, that work engagement and interpersonal strain are related to intention to quit positively and negatively, respectively, and that work engagement and interpersonal strain mediate the relationship between PoSC and intention to quit.

\section{Materials and Methods}

The study was conducted in an Italian private organisation operating in a large retail chain. Managers were contacted by researchers, requesting authorisation to contact the workers. All workers were informed about the research through meetings with researchers. Ethical guidelines were followed, and informed consent was obtained from all individual participants included in the study.

Participation was completely voluntary, and the questionnaire guaranteed anonymity. The response rate was approximately 77\%. A total of 647 workers, $49 \%$ men and 51\% women, completed the questionnaire. The average age of the respondents was 35 years old $(\mathrm{SD}=8.2$ ), ranging from 20 to 63 years old. Regarding the education level, $62 \%$ of participants had a high-school diploma, 5\% completed a Bachelor's or Master's Degree, and $33 \%$ qualified lower than a diploma level. In relation to the job, $71 \%$ of the participants hold the role of salesperson, $20 \%$ of department head, and the rest of the participants hold specialised roles. The average job tenure was $4.6(\mathrm{SD}=4.4)$ years.

\subsection{Measures}

Perceptions of Social Context (PoSC). This scale has been previously validated in the same organisational context [38] and consolidated through a meta-analytic procedure in various organisations [45]. Six items measured the Perception of top management's actions in terms of orientation towards employees' development and growth, the communication of organisational goals, procedures and policies, the integration of different units, and the fair treatment of workers (e.g., "Top management provides clear guidelines"; "Top management is interested in employees' well-being"). Cronbach's alpha was 0.94. Five items measured the Perception of the supervisor in supporting coworkers, encouraging their involvement, and treating them equally (e.g., "My immediate supervisor guarantees all the assistance I need in order to best carry-out my job"; "My immediate supervisor takes care of my professional growth"). The reliability alpha was 0.94 . Six items measured the Perception of colleagues with regard to social cohesion, reciprocal trust and respect, mutual support and cooperation in facing obstacles, and the integration of each member's competencies to complete tasks (e.g., "In my office we work in a friendly atmosphere"; "In my group there is good collaboration, even during periods of difficulty and overload"). The reliability alpha was 0.90 .

For each statement, respondents expressed their agreement on a 7-point scale ranging from 1 (strongly disagree) to 7 (strongly agree).

Interpersonal Strain. Interpersonal strain at work was measured by six items that describe mental and emotional detachment from other people in work contexts [32]. An example item is: "At work, I feel more comfortable keeping distance from others". Cronbach's alpha was 0.93 .

Work Engagement. This construct was measured using the Italian version [82] of the Utrecht Work Engagement Scale [77]. All 9 items, such as "I feel happy when I am working intensively" and "I am immersed in my work", were assessed using a seven-point frequency rating scale ranging from 1 to 7 where $1=$ never and $7=$ always. The reliability alpha was 0.94 .

Intention to Quit. Intention to quit was measured using Firth, Mellor, Moore, and Loquet's scale [83]. This scale aims to measure the strength of participants' intention to leave. The instrument consists of two items and is scored on a 5-point scale where $5=$ Very often and 1 = Rarely or Never, and included the following two items: "How often do you 
think of leaving your present job?" and "How likely are you to look for a new job within the next year?". The reliability alpha was 0.78 .

\subsection{Statistical Analyses}

As a first step, zero-order correlations among variables were explored by using SPSS 24.

Hence, in order to investigate the posited relationships among the variables, a structural equations model was tested using Mplus 7 [84]. The following criteria were employed to evaluate the goodness of fit of the model, and the following multiple indexes were employed: $\chi^{2}$ likelihood ratio statistic, the Tucker and Lewis index (TLI), comparative fit index (CFI), the root mean square error of approximation (RMSEA), and the standardised root mean square residual (SRMR). The chi-square significance value is sensitive to large sample sizes and easily produces a statistically significant result [85]. We accepted TLI and CFI values greater than 0.90, and RMSEA and SRMR values lower than 0.08 [86].

The PoSC of top management, immediate supervisors, and colleagues were included in the model as latent factors, measured by their items (five for supervisors and six for both colleagues and management). Work engagement, interpersonal strain, and intention to quit were also included as latent factors, loaded by seven, six, and two items, respectively.

\section{Results}

Table 1 presents the zero-order correlations among the PoSC of top management, immediate supervisors, colleagues, work engagement, interpersonal strain, and intention to quit.

Table 1. Zero-order correlations and descriptive statistics.

\begin{tabular}{|c|c|c|c|c|c|c|c|c|c|}
\hline & & (1) & (2) & (3) & (4) & (5) & (6) & MEAN & SD \\
\hline 1. & Perceptions of supervisor & 1 & & & & & & 5.31 & 1.55 \\
\hline 2. & Perceptions of colleagues & $0.56^{* *}$ & 1 & & & & & 5.03 & 1.25 \\
\hline 3. & Perceptions of management & $0.69^{* *}$ & $0.56^{* *}$ & 1 & & & & 5.24 & 1.43 \\
\hline 4. & Work engagement & $0.43^{* *}$ & $0.33^{* *}$ & $0.46^{* *}$ & 1 & & & 5.46 & 1.02 \\
\hline 5. & Interpersonal strain & $-0.15^{* *}$ & $-0.28 * *$ & $-0.20 * *$ & $-0.14^{* *}$ & 1 & & 1.79 & 0.98 \\
\hline 6. & Intention to quit & $-0.30 * *$ & $-0.21 * *$ & $-0.38 * *$ & $-0.47^{* *}$ & $0.22 * *$ & 1 & 1.60 & 0.95 \\
\hline
\end{tabular}

Note. $\mathrm{SD}=$ Standard deviation. ${ }^{* *} p<0.01$.

As expected, the PoSC and work engagement were positively correlated but negatively so with interpersonal strain and intention to quit. Moreover, interpersonal strain was positively correlated with intention to quit.

The measurement model fitted the data well: $\chi^{2}(512)=1118.100, p<0.001 ; C F I=0.941$; $T L I=0.936 ; R M S E A=0.043, \mathrm{p}=1.000 ; S R M R=0.043$. The factor loadings were all significantly different from zero and greater than 0.30 (ranging from 0.59 to 0.95 ), confirming the appropriateness of each item as an indicator of the hypothesised latent factor.

The posited structural model, represented in Figure 2, also fitted the data well with fit indices equal to those of the measurement model.

Hypotheses 1 and 2, concerning the role of perceptions of social context in predicting work engagement and interpersonal strain, were partially supported: as expected, the PoSC of the immediate supervisors and top management were positively related to work engagement ( $\beta=0.16$ and 0.35 , respectively), while the PoSC of colleagues were negatively related to interpersonal strain $(\beta=-0.31)$. However, the PoSC of immediate 
supervisors and top management were unrelated to interpersonal strain, as well as the

PoSC of colleagues unrelated to work engagement.

\section{Fit indices: \\ $\chi 2(512)=1118.100, \mathrm{p}<.001, \mathrm{CFI}=.941, \mathrm{TLI}=.936, \mathrm{RMSEA}=.043, \mathrm{SRMR}=.043$.}

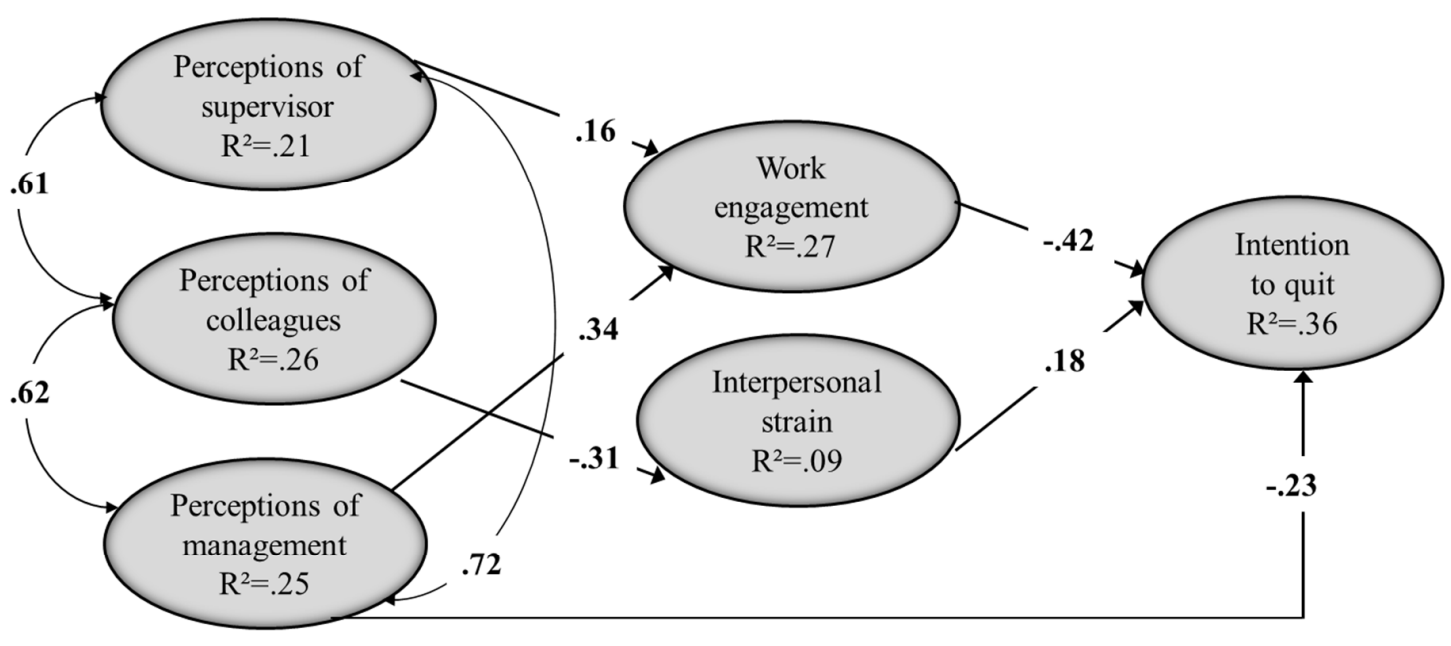

\section{Specific standardized indirect effects:}

- perceptions of supervisor $\rightarrow$ work engagement $\rightarrow$ intention to quit: $\beta=-.07$;

- perceptions of colleagues $\rightarrow$ interpersonal strain $\rightarrow$ intention to quit: $\beta=-.06$;

- perceptions of management $\rightarrow$ work engagement $\rightarrow$ intention to quit: $\beta=-.14$.

Figure 2. Results from structural equation analyses. Notes. Significant coefficients are in bold and on solid lines. Nonsignificant coefficients are not represented.

Hypothesis 3, concerning the expected relationships between job attitudes and turnover intention, was supported: indeed, intention to quit was negatively predicted by work engagement $(\beta=-0.42)$ but positively by interpersonal strain $(\beta=0.18)$.

Hypothesis 4, regarding the relationships between the PoSC and turnover intention, was partially supported. Moreover, the PoSC of immediate supervisors were related to intention to quit indirectly through work engagement $(\beta=-0.07)$. The PoSC of colleagues were also related to the outcome indirectly through interpersonal strain $(\beta=-0.06)$. Finally, the PoSC of top management were related to intention to quit both directly $(\beta=-0.23)$ and indirectly through work engagement $(\beta=-0.14)$. In other words, the results suggest that the PoSC of immediate supervisors and of colleagues were negatively linked to intention to quit through fully mediated relationships, while the PoSC of top management also negatively predict the outcome but through a partially mediated relationship.

\section{Discussion}

The general aim of this study was to analyse the predictive role of PoSC, work engagement, and interpersonal strain on intention to quit. A series of conclusions are drawn up from the results.

Our findings substantially confirmed the hypothesised relationships among the study variables.

First, two significant relationships were found: one between the PoSC of immediate supervisors and work engagement and the second between the PoSC of top management and work engagement (Hypothesis 1). Our results showed that the PoSC of supervisors 
and management have a positive direct effect on employees' levels of engagement in the workplace. This result corroborates the findings of Consiglio and colleagues [51], which showed that an increase in PoSC contributes to work engagement and supports previous studies that considered the perception of a supportive, fair, and loyal supervisor that arouses enthusiasm in their employees, makes the workplace a pleasant place to stay and work [53,56-58], and identifies social support as an important antecedent of employees' work engagement $[55,59,76]$. The results underline how much the engagement of workers is positively related to the perceptions of how supervisors are supportive, value the subordinate's competencies, and take care of their development and professional growth. Furthermore, the engagement is related to the perceptions of how top management encourages individual development, promotes equity, and offers opportunities to satisfy each individual's inclinations.

Second, the PoSC of colleagues was significantly associated with the perceived stress from relationships (Hypothesis 2). In this regard, we found that the PoSC of colleagues were directly related to interpersonal strain, on which they impact in terms of decrement. This result expanded previous research findings that showed a negative relationship between the PoSC of colleagues in teamwork and interpersonal strain [42]. Consistent with these results, the individuals that have a positive perception of the relationship experiences at work avoid disinvesting from these relationships. Therefore, the relationships with colleagues perceived as being characterised by warmth, respect, trust, and pleasure prevent an attitude of distance and withdrawal from relationships at work.

Third, significant relationships were found between work engagement and intention to quit and between interpersonal strain and intention to quit (Hypothesis 3). Additionally, interpersonal strain and work engagement impact the outcome in terms of decrement and increment, respectively. These results expand, on the one hand, the nascent line of research concerning the relationship of interpersonal strain with turnover intentions and corroborate, on the other hand, the empirical evidence about the influence of work engagement on the intention to leave the organisation $[11,12,33,35,68-70,72,73,75]$. As shown by our results, in fact, intention to quit is favoured when there is discomfort and detached relationships at work due to relational pressures and is prevented when employees are strongly engaged in their work.

Finally, our findings support the mediating role of work engagement and interpersonal strain in linking PoSC with turnover intention, as hypothesised (Hypothesis 4). Specifically, we found that work engagement wholly mediates the effect of the PoSC of immediate supervisors and partially mediates the effect of the PoSC of top management on intention to quit. As regards this latter effect, in fact, the PoSC of top management also have a direct effect on turnover intention [11]. Furthermore, we showed that the interpersonal strain wholly mediates the effect of the perceptions of colleagues on the intention to leave work [15].

Our model highlights how all three measured perceptions of social context, which represent perceptions of prototypic components within organisational settings, have a role in the process that leads individuals to develop the intention to leave, albeit in a different way. The positive perception of an attentive and supportive direct supervisor decreases intention to quit through the strengthening of work engagement, while the positive perception of colleagues intervenes on the intention to quit through a reduction of interpersonal strain. The perceptions of top management, oriented to define organisational procedures and policies which have an impact on the organisation of work and on the working life of employees, however, have a crucial role in that they act on turnover intention both through the reinforcement of work engagement and directly. Moreover, it is interesting to underline that it is through work engagement that the perception of daily interface roles with workers (as supervisors) affects the intention to leave the organisation, just as that it is through strain related to working relationships that perception related to social relationships between peers (as colleagues) affects turnover intention. However, perceptions related to something that is more distant but crucial in organisational life 
directly impacts the intention to leave. In summary, work engagement and interpersonal strain are a key link between the PoSC and intention to change organisations; in fact the PoSC alone cannot act strongly on the intention to leave.

\section{Conclusions}

All in all, this study enriches the literature on turnover intentions and its predictors, focusing on the role played by a new construct as the perceptions of social context; by two dimensions, represented by a positive motivational state, namely work engagement; and by a negative psychological condition linked to discomfort in relationships at work, namely interpersonal strain. The results are promising from a theoretical and application point of view and offer suggestions to prevention interventions promoting healthy, productive, and sustainable workplaces.

From an application standpoint, the presented results provide several practical implications for various corporate stakeholders as administrators, peers, managers, customers, and society.

First, given the validity and reliability of the PoSC scale, this tool can be used to measure PoSC in a reliable manner and repeated over time to plan subsequent actions to improve work engagement and prevent relational stress, as well as the intention to leave work. The study suggests how vital it is to act on the PoSC related to the social component by planning actions that involve management with interventions aimed at improving the degree of collaboration between colleagues and supervisors. Our results highlight the need for top management to care about clarity and transparency in communications, equity, trust, and integration to improve the experience of being engaged at work and prevent the intention to leave the organisation. Specifically, to improve the perception of the top management, the immediate supervisor could adopt strategies aimed at involving workers in issues inherent in the organisation through periodic formal and informal meetings and create opportunities to learn both on the job through moments of confrontation between colleagues and through specific training. Training may help to develop the quality of relationships between supervisors and workers, between managers and workers, and with colleagues, not only in relation to work engagement but also to turnover intention. In addition, to prevent or intervene in discomforting and disengaging relationships at work, data suggest acting on the quality of colleagues' relationships.

Second, as previously underlined, work engagement plays a key role in preventing intention to quit, further supporting its significance as a factor that can represent a competitive advantage in retaining workers inside the organisation. Different interventions can also be suggested to HR managers to enhance work engagement. In accordance with Bakker [87], four bottom-up approaches can be used in order to increase work engagement: self-management, job crafting, strengths use, and mobilising ego resources. Starting from our findings and including Bakker's suggestions, we propose planning training to teach employees to assess their performances according to personal standards they set, to manage demands and job resources in their own job to attain and optimise their personal working goals, to use strategies focused on their qualities or strengths, and to proactively mobilise their own energetic, affective, and cognitive resources.

Third, given the role played by reducing interpersonal strain in mediating the process through which perceptions of colleagues prevent the intention to quit, it is crucial to further regulate the overall risk of the development of interpersonal strain. In this regard, the organisation could periodically monitor its level and, when necessary, could implement interventions aimed at managing relational problems, such as actions of individual-level or group-level counselling.

In summary, this study suggests the need to improve supervisor-employee interaction and collaboration by stimulating relationships based on dialogue and promoting communication based on trust, reciprocity, and feedback. This requires suitable managerial skills that should be promoted through specific training to supervisors aimed at developing a greater ability to support their employees. Finally, human resource management policies 
and practices aimed at rewarding appropriate employee behaviours could reinforce support levels and have a positive influence on work engagement by reducing employees' interpersonal strain and turnover intention. Human resources management practices should focus on employee competencies for active customer engagement, which positively influences organisational success. A limitation of this study is that its research design is cross-sectional, thus making it difficult to comprehensively examine the causal relationship. Furthermore, this study is based on self-report measures, and it is possible that common method variance may inflate the scores. However, the best informants (regarding PoSC, work engagement, and relational strain), as previously recognised, are individuals. In addition, future research should seek to replicate this study by implementing a longitudinal research design and including additional measures as negative perceptions of supervisor and colleagues and/or objective measures (such as actual turnover data) to confirm the predictive validity of our model. Future research could replicate this study including other retail personnel in order to reinforce the findings of the present research by adding customer engagement and satisfaction measures.

Author Contributions: Conceptualization, S.D.S. and L.B.; Formal analysis, G.C. and R.C.; Methodology, G.C. and R.C.; Supervision, S.D.S. and L.B.; Writing-original draft, S.D.S. and G.C.; Writingreview \& editing, S.D.S. and L.B. All authors have read and agreed to the published version of the manuscript.

Funding: This research received no external funding.

Institutional Review Board Statement: The study was conducted according to the guidelines of the Declaration of Helsinki, and approved by the Ethics Committee of Department of pedagogy, psychology, and philosophy, University of Cagliari (protocol 12/2017).

Informed Consent Statement: Informed consent was obtained from all subjects involved in the study.

Data Availability Statement: Data sharing not applicable.

Conflicts of Interest: The authors declare no conflict of interest.

\section{References}

1. Pluta, A.; Rudawska, A. Holistic approach to human resources and organizational acceleration. J. Organ. Chang. Manag. 2016, 29, 293-309. [CrossRef]

2. Van den Heuvel, M.; Demerouti, E.; Bakker, A.B.; Schaufeli, W.B. Personal resources and work engagement in the face of change. In Contemporary Occupational Health Psychology: Global Perspectives on Research and Practice; Houdmont, J., Leka, S., Eds.; Wiley: Chichester, UK, 2010; pp. 124-150. [CrossRef]

3. Di Fabio, A.; Kenny, M.E. From decent work to decent lives: Positive self and relational management (PS\&RM) in the twenty-first century. Front. Psychol. 2016, 7, 361. [CrossRef]

4. Di Fabio, A. The psychology of sustainability and sustainable development for well-being in organizations. Front. Psychol. 2017, 8, 1534. [CrossRef]

5. Di Fabio, A.; Peiró, J.M. Human Capital Sustainability Leadership to promote sustainable development and healthy organizations: A new scale. Sustainability 2018, 10, 2413. [CrossRef]

6. Di Fabio, A.; Gori, A. Assessing workplace relational civility (WRC) with a new multidimensional "mirror" measure. Front. Psychol. 2016, 7, 890. [CrossRef]

7. Di Fabio, A.; Gori, A. Developing a new instrument for assessing acceptance of Change. Front. Psychol. 2016, 7, 802. [CrossRef]

8. Manuti, A.; Giancaspro, M.L. People make the difference: An explorative study on the relationship between organizational practices, employees' resources, and organizational behavior enhancing the psychology of sustainability and sustainable development. Sustainability 2019, 11, 1499. [CrossRef]

9. Di Fabio, A.; Rosen, M.A. Opening the black box of psychological processes in the science of sustainable development: A new frontier. Eur. J. Sustain. Dev. Res. 2018, 2, 47. [CrossRef]

10. Avey, J.B.; Luthans, F.; Jensen, S.M. Psychological capital: A positive resource for combating employee stress and turnover. Hum. Resour. Manag. 2009, 48,677-693. [CrossRef]

11. Saks, A.M. Antecedents and consequences of employee engagement. J. Manag. Sychol. 2006, 21, 600-619. [CrossRef]

12. Schaufeli, W.B.; Bakker, A.B. Job demands, job resources and their relationship with burnout and engagement: A multiple-sample study. J. Organ. Behav. 2004, 25, 293-315. [CrossRef]

13. Xiong, R.; Wen, Y. Employees' turnover intention and behavioral outcomes: The role of work engagement. Soc. Behav. Personal. Int. J. 2020, 48, 1-7. [CrossRef] 
14. Podsakoff, N.P.; LePine, J.A.; LePine, M.A. Differential challenge stressor-hindrance stressor relationships with job attitudes, turnover intentions, turnover, and withdrawal behavior: A meta-analysis. J. Appl. Psychol. 2007, 92, 438. [CrossRef]

15. Shaukat, R.; Yousaf, A.; Sanders, K. Examining the linkages between relationship conflict, performance and turnover intentions: Role of job burnout as a mediator. Int. J. Confl. Manag. 2017, 28, 4-23. [CrossRef]

16. Davidson, M.C.; Timo, N.; Wang, Y. How much does labour turnover cost? A case study of Australian four-and five-star hotels. Int. J. Contemp. Hosp. Manag. 2010, 22, 451-466. [CrossRef]

17. Dusek, G.A.; Ruppel, C.P.; Yurova, Y.; Clarke, R. The role of employee service orientation in turnover in the US hotel industry. J. Organ. Cult. Commun. Confl. 2014, 18, 87.

18. Chi, C.G.; Gursoy, D. Employee satisfaction, customer satisfaction, and financial performance: An empirical examination. Int. J. Hosp. Manag. 2009, 28, 245-253. [CrossRef]

19. Eberly, M.B.; Holtom, B.C.; Lee, T.W.; Mitchell, T.R. Control voluntary turnover by understanding its causes. In Handbook of Principles of Organizational Behavior, 2nd ed.; Locke, E.A., Ed.; John Wiley \& Sons, Ltd.: Chichester, UK, 2009. [CrossRef]

20. Long, C.S.; Thean, L.Y. Relationship between leadership style, job satisfaction and employees' turnover intention: A literature review. Res. J. Bus. Manag. 2011, 5, 91-100. [CrossRef]

21. Salleh, R.; Nair, M.S.; Harun, H. Job satisfaction, organizational commitment, and turnover intention: A case study on employees of a retail company in Malaysia. World Acad. Sci. Eng. Technol. 2012, 72, 316-323.

22. Alam, A.; Asim, M. Relationship between job satisfaction and turnover intention. Int. J. Hum. Resour. Studies. ISSN 2019, 2162-3058. [CrossRef]

23. Chiu, R.K.; Francesco, A.M. Dispositional traits and turnover intention: Examining the mediating role of job satisfaction and affective commitment. Int. J. Manpow. 2003, 24, 284-298. [CrossRef]

24. Bigliardi, B.; Petroni, A.; Ivo Dormio, A. Organizational socialization, career aspirations and turnover intentions among design engineers. Leadersh. Organ. Dev. J. 2005, 26, 424-441. [CrossRef]

25. Griffeth, R.W.; Hom, P.W.; Gaertner, S. A meta-analysis of antecedents and correlates of employee turnover: Update, moderator tests, and research implications for the next millennium. J. Manag. 2000, 26, 463-488. [CrossRef]

26. Hom, P.W.; Caranikas-Walker, F.; Prussia, G.E.; Griffeth, R.W. A meta-analytical structural equations analysis of a model of employee turnover. J. Appl. Psychol. 1992, 77, 890. [CrossRef]

27. Dawley, D.; Houghton, J.D.; Bucklew, N.S. Perceived organizational support and turnover intention: The mediating effects of personal sacrifice and job fit. J. Soc. Psychol. 2010, 150, 238-257. [CrossRef] [PubMed]

28. Chang, W.J.A.; Wang, Y.S.; Huang, T.C. Work design-related antecedents of turnover intention: A multilevel approach. Hum. Resour. Manag. 2013, 52,1-26. [CrossRef]

29. Aydogdu, S.; Asikgil, B. An empirical study of the relationship among job satisfaction, organizational commitment and turnover intention. Int. Rev. Manag. Mark. 2011, 1, 43-53.

30. Ekhsan, M. The influence job satisfaction and organizational commitment on employee turnover intention. J. Bus.Manag. Account. 2019, 1, 48-55.

31. Borgogni, L.; Armandi, F.; Amaducci, M.; Consiglio, C. Integrazione alla misura del job burnout: La scala di sovraccarico relazionale. G. Ital. Psicol. 2007, 34, 699-714. [CrossRef]

32. Borgogni, L.; Consiglio, C.; Alessandri, G.; Schaufeli, W.B. "Don't throw the baby out with the bathwater!" Interpersonal strain at work and burnout. Eur. J. Work Organ. Psychol. 2012, 21, 875-898. [CrossRef]

33. Simpson, M.R. Engagement at work: A review of the literature. Int. J. Nurs. Stud. 2009, 46, 1012-1024. [CrossRef]

34. Memon, M.A.; Salleh, R.; Baharom, M.N.R.; Harun, H. Person-Organization Fit and Turnover Intention: The Mediating Role of Employee Engagement. Glob. Bus. Manag. Res. 2014, 6. [CrossRef]

35. De Simone, S.; Planta, A.; Cicotto, G. The role of job satisfaction, work engagement, self-efficacy and agentic capacities on nurses' turnover intention and patient satisfaction. Appl. Nurs. Res. 2018, 39, 130-140. [CrossRef]

36. Pinna, R.; De Simone, S.; Cicotto, G.; Malik, A. Beyond organisational support: Exploring the supportive role of co-workers and supervisors in a multi-actor service ecosystem. J. Bus. Res. 2020, 121, 124-134. [CrossRef]

37. Latham, G.P.; Borgogni, L.; Petitta, L. Goal setting and performance management in the public sector. Int. Public Manag. J. 2008, 11, 385-403. [CrossRef]

38. Borgogni, L.; Dello Russo, S.; Petitta, L.; Latham, G.P. Collective efficacy and organizational commitment in an Italian city hall. Eur. Psychol. 2009, 14, 363-371. [CrossRef]

39. Consiglio, C.; Borgogni, L.; Vecchione, M.; Maslach, C. Self-efficacy, Perceptions of Social Context, and burnout: A multilevel study on nurses. Med. Lav. 2014, 105, 255-268.

40. Borgogni, L.; Dello Russo, S.; Petitta, L.; Vecchione, M. Predicting job satisfaction and job performance in a privatized organization. Int. Public Manag. J. 2010, 13, 275-296. [CrossRef]

41. Borgogni, L.; Petitta, L.; Mastrorilli, A. Correlates of collective efficacy in the Italian Air Force. Appl. Psychol. 2010, 59, 515-537. [CrossRef]

42. De Simone, S.; Cicotto, G.; Borgogni, L. Il ruolo delle Percezioni di Contesto sul Job Burnout nelle organizzazioni sanitarie. Med. Lav. 2018, 109, 264-275. [CrossRef] [PubMed]

43. Caprara, G.V.; Barbaranelli, C.; Borgogni, L.; Steca, P. Efficacy beliefs as determinants of teachers' job satisfaction. J. Educ. Psychol. 2003, 95, 821-832. [CrossRef] 
44. Caprara, G.V.; Barbaranelli, C.; Borgogni, L.; Petitta, L.; Rubinacci, A. Teachers', school staff's and parents' beliefs as determinants of attitude toward school. Eur. J. Psychol. Educ. 2003, 18, 15-31. [CrossRef]

45. Borgogni, L.; Dello Russo, S.; Latham, G.P. The relationship of employee perceptions of the immediate supervisor and top management with collective efficacy. J. Leadersh. Organ. Stud. 2011, 18, 5-13. [CrossRef]

46. Consiglio, C.; Borgogni, L.; Alessandri, G.; Schaufeli, W.B. Does self-efficacy matter for burnout and sickness absenteeism? The mediating role of demands and resources at the individual and team levels. Work Stress 2013, 27, 22-42. [CrossRef]

47. Griffin, M.A. Specifying Organizational Contexts: Systematic Links Between Contexts and Processes in Organizational Behavior. J. Organ. Behav. 2007, 28, 859-863. [CrossRef]

48. Johns, G. Reflections on the 2016 decade award: Incorporating context in organizational research. Acad. Manag. Rev. 2017, 42, 577-595. [CrossRef]

49. Johns, G. Advances in the treatment of context in organizational research. Annu. Rev. Organ. Psychol. Organ. Behav. 2018, 5, 21-46. [CrossRef]

50. Johns, G. The Essential Impact of Context on Organizational Behavior. Acad. Manag. Rev. 2006, 31, 386-408. [CrossRef]

51. Consiglio, C.; Borgogni, L.; Di Tecco, C.; Schaufeli, W.B. What makes employees engaged with their work? The role of self-efficacy and employee's perceptions of social context over time. Career Dev. Int. 2016, 21, 125-143. [CrossRef]

52. Schaufeli, W.B.; Bakker, A.B. Defining and measuring work engagement: Bringing clarity to the concept. In Work Engagement: A Handbook of Essential Theory and Research; Bakker, A.B., Leiter, M.P., Eds.; Psychology Press: New York, NY, USA, 2010; pp. 10-24. [CrossRef]

53. Bakker, A.B.; Schaufeli, W.B.; Leiter, M.P.; Taris, T.W. Work engagement: An emerging concept in occupational health psychology. Work Stress 2008, 22, 187-200. [CrossRef]

54. Schaufeli, W.B.; Salanova, M.; González-Romá, V.; Bakker, A.B. The measurement of engagement and burnout: A two sample confirmatory factor analytic approach. J. Happiness Stud. 2002, 3, 71-92. [CrossRef]

55. Hakanen, J.; Bakker, A.B.; Schaufeli, W.B. Burnout and work engagement among teachers. J. Sch. Psychol. 2006, 43, 495-513. [CrossRef]

56. Bakker, A.B.; Demerouti, E. Towards a model of work engagement. Career Dev. Int. 2008, 13, 209-223. [CrossRef]

57. Halbesleben, J.R.B. A meta-analysis of work engagement: Relationships with burnout, demands, resources, and consequences. In Work Engagement: A Handbook of Essential Theory and Research; Bakker, A.B., Leiter, M.P., Eds.; Psychology Press: New York, NY, USA, 2010; pp. 102-117.

58. Schaufeli, W.B.; Salanova, M. Work engagement: An emerging psychological concept and its implications for organizations. In Research in Social Issues in Management: Managing Social and Ethical Issues in Organizations; Gilliland, S.W., Steiner, D.D., Skarlicki, D.P., Eds.; Information Age Publishers: Greenwich, CT, USA, 2007; Volume 5. [CrossRef]

59. Korunka, C.; Kubicek, B.; Schaufeli, W.B.; Hoonakker, P. Work engagement and burnout: Testing the robustness of the jobsdemands resources model. J. Posit. Psychol. 2009, 4, 243-255. [CrossRef]

60. Bakker, A.B.; Demerouti, E. The job demands-resources model: State of the art. J. Manag. Psychol. 2007, 22, 309-328. [CrossRef]

61. Shantz, A.; Alfes, K.; Latham, G.P. The buffering effect of perceived organizational support on the relationship between work engagement and behavioral outcomes. Hum. Resour. Manag. 2016, 55, 25-38. [CrossRef]

62. Hakanen, J.J.; Lindbohm, M.L. Work engagement among breast cancer survivors and the referents: The importance of optimism and social resources at work. J. Cancer Surviv. 2008, 2, 283-295. [CrossRef]

63. Kinnunen, U.; Feldt, T.; Mäkikangas, A. Testing the effort-reward imbalance model among Finnish managers: The role of perceived organizational support. J. Occup. Health Psychol. 2008, 13, 114. [CrossRef]

64. Taris, T.W.; van Horn, J.; Schaufeli, W.B.; Schreurs, P. Inequity, burnout and psychological withdrawal among Dutch teachers: A dynamic exchange model. Anxiety Stress Coping 2004, 17, 103-122. [CrossRef]

65. Consiglio, C. Interpersonal strain at work: A new burnout facet relevant for the health of hospital staff. Burn. Res. 2014, 1, 69-75. [CrossRef]

66. Laschinger, H.K.S.; Borgogni, L.; Consiglio, C.; Read, E. The effects of authentic leadership, six areas of worklife, and occupational coping self-efficacy on new graduate nurses' burnout and mental health: A cross-sectional study. Int. J. Nurs. Stud. 2015, 52, 1080-1089. [CrossRef]

67. Dello Russo, S.; Miraglia, M.; Borgogni, L.; Johns, G. How time and perceptions of social context shape employee absenteeism trajectories. J. Vocat. Behav. 2013, 83, 209-217. [CrossRef]

68. Bakker, A.B.; Demerouti, E. Job demands-Resources theory: Taking stock and looking forward. J. Occup. Health Psychol. 2016, 1-13. [CrossRef]

69. Halbesleben, J.R.; Wheeler, A.R. The relative roles of engagement and embeddedness in predicting job performance and intention to leave. Work Stress 2008, 22, 242-256. [CrossRef]

70. Agarwal, U.A.; Datta, S.; Blake-Beard, S.; Bhargava, S. Linking LMX, innovative work behaviour and turnover intentions: The mediating role of work engagement. Career Dev. Int. 2012, 17, 208-230. [CrossRef]

71. Brunetto, Y.; Teo, S.T.; Shacklock, K.; Farr-Wharton, R. Emotional intelligence, job satisfaction, well-being and engagement: Explaining organisational commitment and turnover intentions in policing. Hum. Resour. Manag. J. 2012, 22, 428-441. [CrossRef]

72. Laschinger, H.K.S. Job and career satisfaction and turnover intentions of newly graduated nurses. J. Nurs. Manag. 2012, 20, 472-484. [CrossRef] [PubMed] 
73. De Simone, S.; Planta, A. L'intenzione di lasciare il lavoro nel personale infermieristico: Il ruolo della soddisfazione lavorativa, dell'autoefficacia e del work engagement. Med. Lav. 2017, 108, 87-97. [CrossRef] [PubMed]

74. Shahpouri, S.; Namdari, K.; Abedi, A. Mediating role of work engagement in the relationship between job resources and personal resources with turnover intention among female nurses. Appl. Nurs. Res. 2016, 30, 216-221. [CrossRef]

75. Hakanen, J.J.; Ropponen, A.; Schaufeli, W.B.; De Witte, H. Who is Engaged at Work?: A Large-Scale Study in 30 European Countries. J. Occup. Environ. Med. 2019, 61, 373-381. [CrossRef]

76. Schaufeli, W.B.; Salanova, M. Burnout, boredom and engagement at the workplace. In People at Work: An Introduction to Contemporary Work Psychology; Peeters, M.C.W., de Jonge, J., Taris, T.W., Eds.; John Wiley \& Sons, Ltd.: New York, NY, USA, 2014; pp. 293-320.

77. Schaufeli, W.B.; Bakker, A.B.; Salanova, M. The measurement of work engagement with a short questionnaire: A cross-national study. Educ. Psychol. Meas. 2006, 66, 701-716. [CrossRef]

78. Fukui, S.; Wu, W.; Salyers, M.P. Impact of Supervisory Support on Turnover Intention: The Mediating Role of Burnout and Job Satisfaction in a Longitudinal Study. Adm. Policy Ment. Health Ment. Health Serv. Res. 2019, 46, 488-497. [CrossRef] [PubMed]

79. Wang, E.; Hu, H.; Mao, S.; Liu, H. Intrinsic motivation and turnover intention among geriatric nurses employed in nursing homes: The roles of job burnout and pay satisfaction. Contemp. Nurse 2019, 55, 195-210. [CrossRef]

80. Moon, Y. Customer-Contact Employee Support and Service Recovery Efforts: The Mediating Role of Job Burnout and Customer Orientation. Asia Mark. J. 2018, 20, 83-103. [CrossRef]

81. Rich, B.L.; LePine, J.A.; Crawford, E.R. Job engagement: Antecedents and effects on job performance. Acad. Manag. J. 2010, 53, 617-635. [CrossRef]

82. Balducci, C.; Fraccaroli, F.; Schaufeli, W.B. Psychometric properties of the Italian version of the Utrecht Work Engagement Scale (UWES-9). Eur. J. Psychol. Assess. 2010, 26, 143-149. [CrossRef]

83. Firth, L.; Mellor, D.J.; Moore, K.A.; Loquet, C. How can managers reduce employee intention to quit? J. Manag. Psychol. 2004, 19, 170-187. [CrossRef]

84. Muthén, L.K.; Muthén, B.O. Mplus User's Guide; Muthén \& Muthén: Los Angeles, CA, USA, 2017.

85. Bollen, K.A. Structural Equations with Latent Variables; John Wiley \& Sons, Inc.: Hoboken, NJ, USA, 1989.

86. Bentler, P.M. Comparative fit indexes in structural models. Psychol. Bull. 1990, 107, 238-246. [CrossRef]

87. Bakker, A.B. Strategic and proactive approaches to work engagement. Organ. Dyn. 2017, 46, 67-75. [CrossRef] 